УДК 327 (091)

Ластовський Валерій Васильович

доктор історичних наук, професор,

Київський наиіональний університет культури і мистещттв,

Київ, Україна,

lastov@ukr.net

\title{
ІСТОРІЯ МІЖНАРОДНИХ ВІДНОСИН: ТЕОРЕТИЧНИЙ ФОРМАТ
}

У статті піднімається питання щодо співвідношення, дослідження і використання теоретичних основ історії міжнародних відносин як достатньо специфічного наукового напряму, який поєднує в собі риси історичних і політичних наук, зокрема всесвітньої історії, історії дипломатії, політології, теорії міжнародних відносин та ін. Поява історії міжнародних відносин пов'язана із розвитком національних історичних наук, дослідженням історії дипломатії, геополітичних концепцій, теорії міжнародних відносин тощо. Результати наукового вивчення історії міжнародних відносин стали основою для вивчення загальних міжнародних процесів. Упродовж усього XX ст. цей напрям активно розвивався і на нього впливало протистояння політичних систем. Відповідно, використовувалися антагоністичні ідеології, здійснювався вибірковий підбір історичних фактів та джерел. Дискусійними на сьогодні залишаються такі питання як поняття та предмет історії міжнародних відносин, періодизація, співвідношення із всесвітньою історією, історією дипломатії, теорією міжнародних відносин та іншими науковими напрямами.

Ключові слова: історія міжнародних відносин, теорія міжнародних відносин, історія дипломатії, системна історія, періодизація.

Lastovskyi Valerii, Doctor of Historical Sciences, Professor, Kyiv National University of Culture and Arts, Kyiv, Ukraine

\section{History of international relations: a theoretical format}

The article deals with the issue on the correlation, study and usage of the international relations history theoretical foundations as a sufficiently specific scientific direction, combining the features of historical and political sciences, in particular world history, the history of diplomacy, political science, the theory of the international relations, etc. The emergence of the international relations history is connected with the development of national historical sciences, the study of the history of diplomacy, geopolitical concepts, the theory of international relations, etc. The results of the scientific study of the international relations history have laid the basis for the common international processes study. Throughout the XX-th century this direction was actively developing, been influenced upon by the confrontation of 
political systems. Accordingly, antagonistic ideologies were used, a sample selection of historical facts and sources was carried out.

Such issues as the concept and the subject of the international relations history, its periodization, and relations with the world history, history of diplomacy, the theory of international relations and other scientific directions still remain controversial.

Key words: the history of international relations, the theory of international relations, the history of diplomacy, the systemic history, periodization.

Ластовский Валерий Васильевич, доктор исторических наук, професор, Киевский национальный университет культуры и искусств, Киев, Украина

\section{История международных отношений: теоретический формат}

В статье ставится вопрос о соотношении, исследовании и использовании теоретических основ истории международных отношений как довольно специфического научного направления, объединяющего в себе черты исторических и политических наук, к примеру всемирной истории, истории дипломатии, политологии, теории международных отношений и др. Появление истории международных отношений связано с развитием национальных исторических наук, изучением истории дипломатии, геополитических концепций, теории международных отношений и др. Результаты научного изучения истории международных отношений стали основой для исследования общих международных процессов. На протяжении всего XX в. это направление активно развивалось и на него влияли антагонистические идеологии, осуществлялся избирательный подбор исторических фактов и источников.

Дискуссионными сегодня остаются такие вопросы как понятие и предмет истории международных отношений, периодизация, соотношение с всемирной историей, историей дипломатии, теорией международных отношений и другими научными направлениями.

Ключевые слова: история международных отношений, теория международных отношений, история дипломатии, ситсемная история, периодизация.

Вступ. Зв'язок між історією та міжнародними відносинами найбільш очевидний серед усіх інших гуманітарних напрямів та серед усіх практичних засобів їх реалізації. Він очевидний, починаючи від звичайних шкільних підручників 3 історії і до концептуальних трактатів філософів-мислителів чи аналітичних записок спеціалізованих державних установ. Цей зв'язок настільки очевидний, що дослідники не часто й звертаються до теми теоретичного обгрунтування історії міжнародних відносин як досить специфічного наукового напряму (чого, наприклад, не можна сказати стосовно теорії міжнародних відносин, яка, у свою чергу, базується саме на історичній інформації та історичних уявленнях). 
Аналіз останніх досліджень. Фактично досліджень на цю тематику в українському науковому просторі майже не існує. В англо-американській історіографії є напрацювання Д. Дж. Пучала, Т. Сміта, Дж. Лоусона, Дж. Хобсона, Х.Л. Малчоу, $\quad$ В. Бейна, $\quad$ Т. Нардіна та iн., $\quad$ в російській В. Романова та В. Асташина.

Формулювання цілей статті. Метою даної публікації є з'ясування специфіки історії міжнародних відносин як наукового напряму, котрий поєднує в собі елементи різних наук і потребує теоретичного обгрунтування з метою найефективнішого дослідження і застосування іiї результатів.

Виклад основного матеріалу. Ще в епоху античності, від часів істориків Геродота та Фукідіда (V ст. до н. е.), з'явилися перші наукові твори, в яких висвітлювалися історія міжнародних відносин. Тоді ж виникли і перші теоретичні уявлення щодо сутності міжнародних відносин як явища. Саме 3

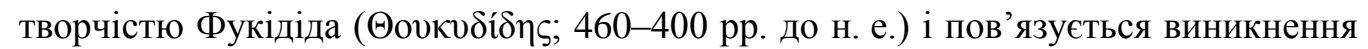
реалістичної парадигми теорії міжнародних відносин. Проте, чи не вперше прив'язав історію міжнародних відносин до історії як науки давньогрецький

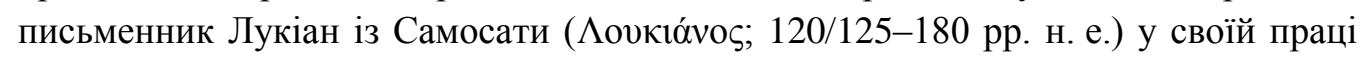
«Як треба писати історію». Зокрема, у т. ч. він пропонував дотримуватися i деяких наукових методологічних засад, наприклад, «автор повинен встигати i, наскільки можливо, переноситись із Вірменії в Мідію, а звідти одним помахом крил в Іберію, потім в Італію, щоб ніде не випустити жодної обставини» [6, c. 647].

Накопичення впродовж наступних більш ніж двох тисячоліть історичної інформації та розвиток самої історичної науки (як і різноманітних суміжних гуманітарних напрямів, що на неї впливали - філософії, соціології, економіки тощо) вивело історію міжнародних відносин фактично в окремий специфічний науковий напрям. Безпосередне народження цього напряму відбулося вже в надрах національних історіографій, які були спрямовані на розкриття передовсім національних історій у контексті світової історії чи, точніше, їх впливу на світову історію.

Цей напрям розвивався одночасно i у тісному поєднанні із такими науками як політологія, геополітика, теорія міжнародних відносин та ін. Власне, результати його розвитку стало видно вже наприкінці XIX - поч. XX ст., коли активно розроблялися і публікувалися дослідження узагальненого характеру саме з історії міжнародних відносин. Наприклад, впродовж 1905-1914 pp. було видано 3-томну «A History of Diplomacy in the international development of Europe», автором якої виступив вчений і дипломат Девід Джейн Хілл (David Jayne Hill; 1850-1932рр.). Він був професором у Школі порівняльного правознавства і дипломатії (Школа міжнародних відносин Елліота), заснованої у 1898 р. в університеті імені Дж. Вашингтона. У той же період з'являється узагальнююча стаття професора Індіанського університету Емоса Херші 
(Amos S. Hershey; 1867-1933 pр.) з історії міжнародних відносин в античності і середньовіччі [12]. Але в цих перших роботах ще відчувається переважання акцентування уваги на дипломатичній історії та історії міжнародного права.

Крім того, необхідно також зауважити, що з XIX ст. 3'явився ще й цілий ряд різноманітних досліджень 3 історії дипломатії, котрі можна вважати певною основою для розвитку історії міжнародних відносин. Достатньо згадати хоча б відому працю французького історика «Histoire diplomatique de l'Europe 1814-1878» Антонена Дебідура (Élie Louis Marie Marc Antonin Debidour; 1847-1917 pp.), видану у 1890 р., але актуальну й до сьогодні.

Саме від рубежу XIX - поч. XX ст. історія міжнародних відносин фактично і стає предметом окремого наукового дослідження. У цьому напрямі працюють як професійні історики, так і теоретики політики в широкому розумінні. Але якщо перші зосереджуються на вивченні достатньо вузьких проблем i питань, то другі (до яких ми відносимо філософів, дипломатів, політиків), відповідно, на більш ширших і узагальнених. Особливістю в цьому $\epsilon$ ще й те, що другі, не будучи професійними істориками, змушені, по-перше, довіряти їх дослідженням, i, по-друге, будувати власні висновки, спираючись саме на них. Один із останніх прикладів такої взаємодії - книга американського політика, дипломата і політолога Генрі Кіссінджера (Henry Alfred Kissinger) 3 його аналізом світової політики [4]. Звичайно, в такій ситуації завжди існуе небезпека вибіркового використання історичної інформації і тому повністю правий Томас Сміт (Thomas W. Smith), коли зауважує у своїй книзі «History and International Relations» (2003), що «історія, яка подібна до політики, викликає ще більше критики».

Історія міжнародних відносин як напрямок достатньо інтенсивно розвивався впродовж ХХ ст., і, звичайно, на нього впливало передовсім протистояння політичних систем в часи «холодної війни», що зумовлювало $\mathrm{i}$ використання відповідної ідеології, риторики та підбору джерел, фактів і їх трактування. У цьому процесі сформувалися дві різних традиції трактування історії міжнародних відносин - радянська (з іiі генетичним наступником сучасною російською) та західна (переважно англо-американська) - за своєю суттю, антагоністичних. Цей антагонізм зберігається й до сьогодні (у зв'язку із трансформацією радянської традиції в сучасну російську). Головною його рисою є розбіжність у тлумаченні історичної ролі держави в сучасному світі. Якщо для західної традиції характерне передовсім тлумачення подій і явищ на основі поліваріативності порядків, то для радянсько-російської традиції моноцентричності. Відповідно, обгрунтування для свого бачення дослідники черпають із бачення історичних процесів на основі, у першому випадку, ліберальної ідеології, а у другому - імперіалістичної (з елементами комуністичної ідеології та шовінізму). Можна порівняти, для прикладу, праці Збігнєва Бжезінського та Олександра Дугіна. Обгрунтування існування особливої 
«російської теорії міжнародних відносин», заснованої на історичній спадкоємності, вже знайшло своє відображення в дискусіях та публікаціях російських дослідників [10].

Щодо українського наукового середовища, то воно впродовж кін. XX - поч. XXI ст. фактично не об'єдналося навколо вибору одного із вищеназваних напрямів, розриваючись між обома.

На сьогодні можна констатувати, що не дивлячись на достатньо значну інформаційну базу джерел та фактів, на значну кількість наукових праць, все ж таки у сфері історії міжнародних відносин залишається чимало суперечливих і нез'ясованих моментів передовсім теоретичного характеру. До них можна віднести, наприклад, питання щодо самого поняття та предмету історії міжнародних відносин, щодо співвідношення цієї історії із іншими науковими напрямами та галузями знань, щодо періодизації, використання джерельної бази тощо.

При цьому, в західній традиції питанням співвідношення історії міжнародних відносин та теорії приділяється досить багато уваги. Так, відомий теоретик, професор Університету Південної Кароліни, Д. Дж. Пучала у своїй відомій монографії взагалі закликав знову повернутися до вивчення історії, в якій він вбачав головну основу теоретичних уявлень [16]. Дослідник ще на початку своєї книги зауважував, що він не $є$ істориком, а скоріше «вченим міжнародних відносин», який намагається подивитися на історію міжнародних відносин за допомогою теорії - «лінз, створених та полірованих теоретиками моєї дисципліни». 3 його точки зору, «історія залишається лабораторією вивчення міжнародних відносин» і цей «робочий простір є насправді набагато більшим, ніж багато хто з теоретиків хотів би це визнати» [16, с. 7].

Також звертають увагу на теоретичні аспекти історії міжнародних відносин й такі сучасні дослідники як Томас Сміт, Джордж Лоусон та Джон Хобсон, Ховард Лерой Малчоу, Вільям Бейн та Террі Нардін та ін. $[13 ; 14 ; 15 ; 17]$. У сучасній російській традиції можна виокремити хіба що публікації В. Романова та В. Асташина, де дійсно ставиться цілий ряд актуальних питань, але сором'язливо зводиться все до викладання навчальної дисципліни $[1 ; 7]$.

Дослідники не дуже часто звертають увагу на саме поняття «Історія міжнародних відносин», очевидно, вважаючи його повністю зрозумілим. Але інколи є й спроби пояснити його. Наприклад, І. Брусиловська, судячи 3 їі думки, вважає предметом вивчення цього напряму «формування міжнародних відносин як системи, що має власні закони, завдання, еволюцію» [2, с. 3].

Тут в першу чергу слід відзначити, що історія міжнародних відносин належить до циклу теоретичних дисциплін і за своїм характером вона є передовсім історичною наукою, хоч і пов' язаною з іншими. Звичайно, вона має свою специфіку, оскільки досліджує виникнення та розвиток регіональних і світових систем 
міжнародних відносин, появу та функціонування міжнародних комунікаційних інститутів, що впливали на історію розвитку міжнародних стосунків взагалі. Але, на відміну від інших дисциплін, вона вивчає конкретні процеси розвитку міжнародних відносин, у тому числі зачіпає проблеми виникнення і розвитку міжнародних організацій, міжнародного права, дипломатичних структур тощо. Тобто історія міжнародних відносин вивчає системи міжнародних стосунків (як регіональні, так і загальносвітові) країн світу в процесі їх розвитку і взаємодії від найдавніших часів у конкретно-історичній обстановці, за принципом хронологічної послідовності, на основі виявлення як загальноісторичних закономірностей цих процесів, так і закономірностей, що діють у рамках тих історичних епох, котрі є найважливішими ступенями в розвитку міжнародного суспільства.

Співвідношення історії міжнародних відносин із цілим рядом наукових напрямів і галузей знань (теорія міжнародних відносин, політологія, теорія держави і права, історія вчень про державу і право та ін.) не викликає особливих питань, оскільки зрозуміло, що історія як наука надає для них фактичний матеріал, а у свою чергу й сама отримує теоретичні напрацювання (уявлення про поняття, принципи, системність, закономірність процесів тощо). Тим не менше, одним із важливих питань все ж таки залишається питання щодо співвідношення історії міжнародних відносин та історії дипломатії чи всесвітньої історії. Спостерігається, зокрема, певне ототожнення цих напрямів. Це можна бачити $\mathrm{i}$ на прикладі того ж дослідження Девіда Джейн Хілла початку XX ст. і в багатьох ін. випадках. Наприклад, відомий радянський історик Борис Поршнєв (1905-1972) писав: «История дипломатии и история войн, словом, история международных отношений, до сих пор оставалась наиболее описательной, фактографической отраслью исторической науки, где обобщения касались более дипломатического и военного искусства, чем сущности самих отношений» [1, c. 130].

Серед сучасних українських дослідників Т. Григор'єва, зосередила свою увагу на історії дипломатії і відзначила, що саме цей напрям дуже довгий час перебував «під впливом методології такої дисципліни як міжнародні відносини» [3, с. 11]. Вочевидь, автор, оминаючи питання щодо історії міжнародних відносин, мала на увазі теорію міжнародних відносин, що й випливає 3 наступного тексту. Та такий підхід дещо звужує взаємодію між всіма цими напрямами. Хоча б тому, що сама історія дипломатії є більш вужчою від історії міжнародних відносин. Звичайно, обидві вони є досить близькими між собою, проте історія дипломатії вивчає передовсім розвиток дипломатичних інститутів та дипломатичної техніки, форм, методів і засобів дипломатичної діяльності в процесі розвитку міжнародних стосунків. Відповідно, історія дипломатії $є$ частиною історії міжнародних відносин настільки, наскільки й сама дипломатія $\epsilon$ частиною міжнародних відносин. Як тут не згадати слова професор із Флоренції 
Енніо ді Нольфо: «Критика деякої обмеженості традиційної дипломатичної історії уявляється обгрунтованою, тому що і сьогодні все ще вважають можливим реконструювати 3 іiі допомогою весь політичний процес змін у міжнародному житті» [11, с. 16].

Можливо, для розуміння співвідношення історії міжнародних відносин 3 іншими напрямами необхідно просто вибудувати відповідну ієрархію (див. табл. 1).

Таблиця 1

\section{Співвідношення історії міжнародних відносин}

з іншими науковими напрямами

\begin{tabular}{|c|c|c|}
\hline & Mren nay & \\
\hline & ТЕОРІЯ МІЖНА & ІХ ВІДНОСИН \\
\hline & ІСТОРІЯ & Історія дипломатії \\
\hline $\begin{array}{l}\text { ВСЕСВІТНЯ } \\
\text { ІСТОРІЯ }\end{array}$ & $\begin{array}{c}\text { МІЖНАРОДНИХ } \\
\text { ВІДНОСИН }\end{array}$ & \\
\hline
\end{tabular}

Далеко не тривіальним є й питання для сучасної науки щодо періодизації історії міжнародних відносин. Тут варто почати з того, що більшість сучасних дослідників починає іiі від 1648 р., від Вестфальського миру, обумовлюючи початком т. зв. «системної історії» (відповідно, практично випускається з уваги весь період більш ранній - «досистемний»). Пояснюють такий підхід, як правило, тим, що саме в період Нового часу почала вимальовуватися глобальна загальносвітова система політичних відносин між державами $[9$, с. 8]. Сучасний український історик І. Хижняк вважає за один із головних методів наукового пошуку поєднання системного принципу із історичним аналізом подій та явищ, у результаті чого з'являється системно-історичний підхід тобто «возможность раскрыть всю динамику развития международных отношений, а не только механизм его функционирования» $[9$, с. 8]. Цю думку підтримали й ін. сучасні українські історики - С. Троян та А. Киридон [8].

Уже традиційно дослідники виділяють 4 історичних системи (Вестфальська, Віденська, Версальсько-Вашингтонська, Ялтинсько-Потсдамська) міжнародних відносин, але інколи дослідники пропонують й ін. підходи. Наприклад, американський дослідник Річард Роузкранц (Richard N. Rosecrance) наполягав на існуванні 9 історичних систем міжнародних відносин від cep. XVIII до сер. XX ст. Але, при цьому, звичайно, можна відштовхуватися і від ще більш традиційного підходу в історії міжнародних відносин, який не буде суперечити системному, проте вкладатиметься у схему загальноісторичну (Стародавній світ, Середньовіччя, Новий час, Новітній час). Звичайно, кожен із таких підходів повинен мати певне обгрунтування і тут $є$ ще про що говорити вченим. Однак, не зайвим буде й ставити питання щодо розширення рамок у підходах до питання щодо періодизації історії міжнародних відносин. У будь- 
якому випадку уявляється, що для історії міжнародних відносин, так само як і для історії держави і права також може бути запропонований підхід висвітлення процесів у контексті розвитку цивілізацій [5, с. 9].

Історія міжнародних відносин - більш ширший предмет, ніж може скластися враження 3 поверхневого погляду. Власне, якщо самі міжнародні відносини охоплюють надзвичайно широкий спектр стосунків (у т.ч. культурних, економічних, релігійних тощо), то відповідно й історія міжнародних відносин у тій чи іншій мірі змушена їх зачіпати. Для прикладу, якщо мова йде про період Середньовіччя, то, зрозуміло, уникнути релігійного фактору у цьому випадку в міжнародних відносинах аж ніяк не можливо. Якщо ж мова буде йти про період Римської імперії, то необхідно буде розглянути й питання щодо культурного взаємопроникнення.

При цьому необхідно враховувати, що впродовж усієї еволюції міжнародних відносин відбувалася зміна формату усіх акторів цих стосунків. Звісно, держава традиційно вважається головним i незмінним актором у міжнародних процесах. Проте, є ряд моментів, на необхідно зважити. Зокрема, хоча б на те, що, по-перше, міжнародні відносини існували ще задовго до появи власне держави (в період міжродових та міжплемінних відносин), по-друге, й сама держава пройшла процес трансформацій (найголовніший - у зв'язку 3 буржуазними революціями XVI-XVIII ст.), по-третє, крім держави, впродовж усієї історії міжнародних відносин все ж таки існували й інші актори (особистості та організаціі). Так, держава була переважаючим суб'єктом у міжнародних відносинах, але, все ж таки, не єдиним.

Висновки. Таким чином, слід відзначити, що історія міжнародних відносин як окремий i специфічний напрям має міжгалузевий характер, поєднуючи в собі елементи історичних та політичних наук, але, разом 3 тим, потребує ще в цілому ряді моментів теоретичного обгрунтування 3 метою найефективнішого дослідження і застосування.

\section{Список використаних джерел:}

1. Асташин В. Методологические проблемы преподавания курса «История международных отношений» (О взаимосвязи истории и теории международных отношений) / В. Асташин // Pro nunc: Современные политические процессы. - 2011. - Т.10, № 1. - С. 130-139.

2. Брусиловська О. Історія міжнародних відносин (сер. III тис. до н.е. сер. XVII ст. н.е.) : навч.-метод. посіб. для студентів ОНУ ім. I. I. Мечникова / О. І. Брусиловська, І. М. Коваль. - Одеса : Одес. нац. ун-т ім. І. І. Мечникова, 2013. $-188 \mathrm{c}$

3. Григор'єва Т. Історія дипломатії: від давнини до кінця XVIII ст. / Т. Григор'єва. - Київ : Видавн. дім «Києво-Могилянська Академія», 2014. $177 \mathrm{c}$. 
4. Кіссінджер Г. Світовий порядок. Роздуми про характер націй в історичному контексті / Г. Кіссінджер. - Київ, 2017. - 320 с.

5. Ластовський В. Історія держави $\mathrm{i}$ права зарубіжних країн / В. Ластовський. - Київ : Вид. центр КНУКіМ, 2017. - 195 с.

6. Лукиан. Избранная проза / Лукиан. - Москва : Правда, 1991. - 720 с.

7. Романов В. История и теория международных отношений: «точки соприкосновения» (из опыта изучения и преподавания зарубежной внешнеполитической мысли) / В. Романов // Pro nunc: Современные политические процессы. - 2011. - Т. 10, № 1. - С. 61-70.

8. Троян С. Структурно-функціональний вимір системного підходу в дослідженнях міжнародних відносин і дипломатії доби Модерну: «Європейський еквілібріум» / С. Троян, А. Киридон // Науковий вісник Дипломатичної академії України. - 2016. - Вип. 23 (1). - С. 199-203.

9. Хижняк И. Системы международных отношений в истории Нового времени / И. Хижняк. - Київ, 2011. - 360 с.

10. Цыганков А. Российская теория международных отношений: какой ей быть? / А. Цыганков // Comparative politics. - 2014. - № 2 (15). - C. 65-83.

11. Эннио ди Нольфо. История международных отношений, 1918-1999 / Эннио ди Нольфо. - Москва, 2003. - 1310 с.

12. Amos S. Hershey. The History of International Relations during Antiquity and the Middle Ages / S. Amos // The American Journal of International Law. 1911. - Vol. 5. - P. 901-933.

13. Bain W. International relations and intellectual history / W. Bain, T. Nardin // International relations. - 2017. - Vol. 31 (3). - P. 213-226.

14. Lawson G. What is history in international relations? / G. Lawson, J. Hobson // Millennium: Journal of International Studies. - 2008. - Vol. 37 (2). P. 415-435.

15. Malchow H. L. History and International Relations: From the Ancient World to the 21th Century / H. L. Malchow. - New York; London, 2016. - 336 p.

16. Puchala D. J. Theory and History in International Relations / D. J. Puchala. - New York; London, 2003. - 288 p.

17. Smith Th. W. History and International Relations / Th. W. Smith London; New York, 2003. - 240 p.

\section{References}

1. Astashyn, V. (2011). Methodological problems of teaching the course "History of International Relations". Pro nunc : Sovremennye politicheskie protcessy [Pro nunc: Contemporary Political Processes], Vol. 10, no 1, pp. 130-139.

2. Brusylovska, O. (2013). The history of international relations (IIId millennium $B C$ - the middle of the XVIIth century AD): educational and methodical manual. Odesa : Odessa I. I. Mechnikov National University. 
3. Hryhorieva, T. (2014). History of diplomacy: from antiquity to the end of the XVIII century. Kyiv : "Kyievo-Mohylianska Akademiia" Publishing House.

4. Kissinger, H. (2017). World Order: Reflections on the Character of Nations and the Course of History. Kyiv.

5. Lastovskyi, V. (2017). History of state and law of foreign countries. Kyiv : KNUKiM Publishing.

6. Lucianus. (1991). Selected Prose. Moscow : Pravda.

7. Romanov, V. (2011). History and theory of international relations: "points of contact" (from the experience of studying and teaching foreign external policy thought). Pro nunc: Sovremennye politicheskie protcessy [Pro nunc: Contemporary Political Processes], Vol. 10, no. 1, pp. 61-70.

8. Troian, S. (2016). Structural and functional dimension of a systematic approach in studies of international relations and diplomacy of the Modern era: "European Equilibrium". Naukovyi visnyk Dyplomatychnoi akademii Ukrainy [Scientific Bulletin of the Diplomatic Academy of Ukraine]. Vol. 23 (1), pp. 199-203.

9. Khizhniak, I. (2011). Systems of international relations in the history of modern times. Kyiv.

10. Tcygankov. A. (2014). The Russian theory of international relations: what should it be? Comparative politics, no. 2 (15), pp. 65-83.

11. Di Nolfo, E. (2003). History of International Relations, 1918-1999. Moscow.

12. Amos, S. Hershey. (1911). The History of International Relations during Antiquity and the Middle Ages. The American Journal of International Law, Vol. 5, pp. 901-933.

13. Bain, W. (2017). International relations and intellectual history. International relations, Vol. 31 (3), pp. 213-226.

14. Lawson, G. (2008). What is history in international relations? Millennium: Journal of International Studies, Vol. 37 (2), pp. 415-435.

15. Malchow, H. L. (2016). History and International Relations: From the Ancient World to the 21th Century. New York; London.

16. Puchala, D. J. (2003). Theory and History in International Relations. New York; London.

17. Smith, Th.W. (2003). History and International Relations. London; New York.

(О) Ластовський В. В., 2018 